\title{
Raise of Nano-Fertilizer Era: Effect of Nano Scale Zinc Oxide Particles on the Germination, Growth and Yield of Tomato (Solanum lycopersicum)
}

\author{
Hajira Khanm $^{1^{*}}$, B.A. Vaishnavi ${ }^{2}$ and A.G. Shankar ${ }^{1}$ \\ ${ }^{1}$ Department of Crop Physiology, UAs, GKVK, Bengaluru, Karnataka, India \\ ${ }^{2}$ Department of Plantation, Spice, Medicine and Aromatic Crops, COH Mudigere, India \\ *Corresponding author
}

\begin{tabular}{|c|}
\hline Keywords \\
\hline $\begin{array}{l}\text { Nano zinc Oxide } \\
(\mathrm{ZnO} N P s), \mathrm{Zinc} \\
\text { sulphate }\left(\mathrm{ZnSO}_{4}\right)\end{array}$ \\
\hline Article Info \\
\hline $\begin{array}{l}\text { Accepted: } \\
16 \text { April } 2018 \\
\text { Available Online: } \\
10 \text { May } 2018\end{array}$ \\
\hline
\end{tabular}

\section{A B S T R A C T}

Globally the soils are Zinc $(\mathrm{Zn})$ deficient and plants are not in a position to accumulate enough $\mathrm{Zn}$ in edible parts that can meet the human nutrition requirement. Nanotechnology is one of the most important tools in modern agriculture. Nano agriculture involves the use of nano sized particles with unique properties (increased uptake by plants as they are small in size and have high rate of penetration through plant cell membrane) to boost crop productivity. In the present study, an attempt was made to study the effect of nano zinc oxide particle ( $\mathrm{ZnO}$ NPs) for improving yield and $\mathrm{Zn}$ content in tomato plant. Initially seed priming concentration were standardized in vitro using $\mathrm{ZnO}$ NPs (400ppm) and granular zinc sulphate $\left(\mathrm{ZnSO}_{4}\right)(800 \mathrm{ppm})$. Further standardized seed priming concentrations with different combinations of treatment such as seed priming, seed priming+ foliar spray and foliar spray were studied under field condition to evaluate their effect on biomass and $\mathrm{Zn}$ accumulation The obtained results based on the physiological and yield parameters showed that the usage of $\mathrm{ZnO}$ NPs fertilizers through any of the method of application has significant positive effect compared to zinc sulphate. ICP-OES analysis of plant digested material revealed that uptake of $\mathrm{ZnO} N \mathrm{Ns}$ is higher than the granular $\mathrm{ZnSO}_{4}$. The present study addresses the potential of nano scale particles on plant system opens an avenue for its potential use as future "nano fertilizers". Thus nanotechnology is one of technologies where lot of scope exists to improve the plant nutrition.

\section{Introduction}

Importance of agriculture to all human societies is characterized more than ever with the increasing world population. The first and most important need of every human is need to access the food, and food supply for humans is associated with agriculture directly or indirectly. The world's population will grow to an estimated 8 billion people by 2025 and 9 billion by 2050, and it is widely recognized that global agricultural productivity must increase to feed a rapidly growing world population (FAO/WHO, 2002). Vegetables and fruits are perishables, and in the absence of effective storage, preservation and transportation, the prices are unstable and the availability uncertain in addition to the above limitation, the diets of the average Indian household did not show any significant improvement over the last few decades of the century. A challenge for global food and 
nutrition security is to feed the world population with nourishing food (Quasem et al., 2009; Ghaly, 2009). Hence emphasis should be laid on production of high quality food with the required level of nutrients and proteins (Pijls et al., 2009; Ghaly and Alkoaik, 2010). To meet this increasing demand, researchers are trying to develop an efficient and ecofriendly production technology based on the innovative technologies.

The issue of micronutrient deficiency is related to food security (Meenakshi et al., 2010; Ghaly and Alkoaik, 2010). Micronutrient deficiencies in human being as well as crop plants are difficult to diagnose and accordingly the problem is termed as 'hidden hunger' (Stein et al., 2008). This hidden hunger may cause nearly 40per cent reductions in crop productivity and also it is estimated that it affects more than a half of the global population. Micronutrient deficiency in general refers to $\mathrm{Fe}, \mathrm{Zn}, \mathrm{Se}, \mathrm{I}, \mathrm{Cu}, \mathrm{Ca}$ and $\mathrm{Mg}$ (Zhao and Mcgrath, 2009), among them Zinc $(\mathrm{Zn})$ deficiency is most wide spread next to Iron, Vitamin A and Iodine. WHO reported that $\mathrm{Zn}$ deficiency stands fifth risk factor for causing diseases among children's in developing countries. Based on analysis of diet composition and nutritional needs, it has been estimated that 49per cent of the world's population (equivalent to 3 billion) are at risk of suffering from $\mathrm{Zn}$ deficiency. Until the recent times, soil fertilization was the only way to meet the mineral requirement of crops plants. However, several problems exist like need for large quantity of fertilizer, fixation in soil and slow uptake by plants.

$\mathrm{Zn}$ has a specific physiological functions in all living systems, such as i) maintenance of structural and functional integrity of biological membranes, ii) as a cofactor for more than 300 enzymes, iii) detoxification of highly toxic oxygen free radicals iv) contribution to protein synthesis and gene expression under normal and stress conditions etc. Among all metals Zn is needed by the largest number of proteins, at least 2800 proteins are $\mathrm{Zn}$ dependent and make up nearly 10 per cent proteomes in eukaryotes, $\mathrm{Zn}$ has a vital role in several body functions such as vision, taste perception, cognition, cell reproduction, growth and immunity, resistance to some infectious diseases such as diarrhoea (Black, 1998) and immunity, (Shankar and Prasad, 1998).

Most of the Indian soils are found to be $\mathrm{Zn}$ deficient, hence the food crops grown in those soils contain less amount of $\mathrm{Zn}$ in food. There has been a significant genetic variability to maintain growth and yield under $\mathrm{Zn}$ deficient conditions among crop species (Hacisalihoglu et al., 2003). Significant variation across crop species and genotypes exists for their ability to $\mathrm{Zn}$ uptake, their sequestration and ability to transport to edible parts.

In order to overcome $\mathrm{Zn}$ disorder, several strategies are being employed including supplementation, fortification, diversification and biofortification. Among these strategies biofortification of food crops with $\mathrm{Zn}$ is considered to be cheaper and sustainable. The simplest of these techniques to increase $\mathrm{Zn}$ content of plants is through the addition of the appropriate mineral as an inorganic compound to the fertilizer. This method has been successful in many instances but depends on the crop species, cultivar, the mineral itself, quality and properties of the soil, making the strategy difficult to apply generally. The major advantages of this method are, it is simple, relatively inexpensive and enhancement can be achieved very rapidly.

However Zn being heavy metal, indiscriminate application of $\mathrm{Zn}$ fertilizers to soil over years will lead to accumulation in soil to the levels toxic to the plants. With the current emphasis on $\mathrm{Zn}$ in agriculture, care should be taken not to get over zealous with 
$\mathrm{Zn}$ applications. Therefore, an efficient mechanism to reduce the amount of $\mathrm{Zn}$ fertilizer application to soil/ foliar without compromising the plant growth and yield is very essential. Hence, in recent years the application of nano scale particle of $\mathrm{Zn}$ is being preferred to enhance agronomic effectiveness of $\mathrm{Zn}$ fertilizers.

Now, after years of green revolution and decline in the ratio of agricultural products to world population growth, it is obvious that there is necessity of employing new technologies in the agriculture industry more than ever. Modern technologies such as bio and nanotechnologies can play an important role in increasing production and improving the quality of food produced by farmers. Many believe that modern technologies will secure growing world food needs as well as deliver a huge range of environmental, health and economic advantages (Wheeler, 2005). Nanotechnology is one of the most important tools in modern agriculture, and agri-food nanotechnology is anticipated to become a driving economic force in the near future. Nanoagriculture focuses currently on target farming that involves the use of nanosized particles with unique properties to boost crop and livestock productivity. The development of nano materials could open up the novel applications in plant biotechnology and soil science. It is anticipated that very soon the industrial production of manufactured nano particles will be increased by manifold and released into the market. However with significant potential benefits, there are considerable uncertainties with regards to potential risks to the environment and human health that needs to be clarified.

The current situation in nanotechnology is one in which there is great potential for benefit but an equally high uncertainty in associated risks. There are evidences for both optimism and pessimism. Pessimism is because of the huge discrepancy between the scale of research being performed on the invention of materials such as nano particles and their associated risks. Optimism is because of the uniquely forward-looking attitude of policy makers and regulators. The unusual properties of nano particles may result in substantially different environmental fate and behaviours than their bulk counterparts but very few observations were made in higher plant growth and yield. Because nano particles are spherical or faceted metal particles typically, <100nm in size. These nanoparticles are having high surface area $\left(30-50 \mathrm{~m}^{2} / \mathrm{g}\right)$, high activity, better catalytic surface, rapid chemical reaction, rapidly dispersible and adsorb abundant water. Thus the implementation of particles in nanometer range can serve as potential alternative to overcome the limitation of presently available fertilizers. So nano fertilizers may increase the efficiency of nutrient uptake, enhance yield and nutrient content in the edible parts and also minimize its accumulation in the soil. Thus present study investigates the effect of ZnO NPs on tomato plants with a view point of their potential use as future" nano fertilizers".

\section{Materials and Method}

\section{Preparation of particle suspension}

Chelated bulk $\mathrm{ZnSO}_{4}$ was used as a reference $\mathrm{Zn}$ source, the materials were suspended directly in deionised water and dispersed by ultrasonic vibration $(100 \mathrm{~W}, 40 \mathrm{KHz})$ for 30 min. Different concentrations $(0,100,200$, 400, 800, 1000, 1500, 2000 ppm) of solutions were prepared. Magnetic bars were placed in the suspensions for stirring to avoid aggregation of the particles. The nano scale suspensions as expected to appeared as clear solutions. The $\mathrm{pH}$ of all the prepared suspensions was found to be 6.8-7.0. A control was also maintained, corresponding to pure water. 


\section{Standardization of $\mathrm{Zn}$ concentration for seed priming}

Tomato seeds were treated with $100 \mathrm{ml}$ of $\mathrm{Zn}$ solutions /suspensions of granular $\mathrm{ZnSO}_{4}$ and $\mathrm{ZnO}$ NPs for three hours. After inhibition seeds were thoroughly washed under running water and allowed for germination. Then the 10 seeds were placed in each petri dish (100 $\mathrm{mm} \times 15 \mathrm{~mm}$ ) with single layer of sterilized filter paper and $5 \mathrm{ml}$ of water was added (as per the recommendations of the International Seed Testing Association, 1976).

Than germination percentage, root length, shoot length were recorded using the values Seedling Vigour Index was calculated by using the formula described by Abdul-Baki and Anderson (1973).

Seed Vigour Index $=$ Germination per cent $x$ (root length + shoot length)

\section{Field experimentation}

Experiment was conducted in the field of Department of Crop Physiology, UAS, GKVK. The experiment was conducted with three different treatments based on method of application of $\mathrm{Zn}$ sources, such as only seed priming, seed priming + foliar application and only foliar application. The standardized $\mathrm{Zn}$ concentrations in nano $\mathrm{ZnO}$ and granular $\mathrm{ZnSO}_{4}$ under lab condition were used as initial seed priming concentrations. And foliar spray was given at 30 DAS (Days after Sowing) Tomato. The concentration maintained for foliar spray was 1 per cent in granular $\mathrm{ZnSO}_{4}$ and 0.5 per cent in nano $\mathrm{ZnO}$.

Physiological parameters were measured at 45 DAS. The following parameters were measured: number of branches, plant height, root length SCMR (Spad Chlorophyll Meter Reading), Relative Water Content (RWC), Specific Leaf Area (SLA),

\section{Relative Water Content (RWC)}

To determine the effect of different treatment in field experiment, RWC was measured. The leaf discs were obtained from plants from replicated treatments, and the fresh weight was determined. Discs were then floated on deionised water for $5 \mathrm{hr}$ under low irradiance, the turgid tissue was then quickly blot dried with tissue paper prior to determining turgid weight. Dry weight was then determined after oven drying at $70^{\circ} \mathrm{C}$ for $48 \mathrm{hr}$. The relative water content was calculated using the formula (Gui-Rui et al., 2000).

RWC $(\%)=\frac{\text { Fresh weight }- \text { dry weight }}{\text { Turgid weight }- \text { dry weight }} \times 100$

Specific Leaf Area (SLA)

SLA was determined using the formula

$\mathrm{SLA}=\frac{\text { Leaf Area }}{\text { Dry weight }} \mathrm{Cm}^{2} / \mathrm{gm}$

\section{Yield and estimation of zinc}

Yield per plant (gm) was recorded. Zinc content was analyzed in different plant parts like leaf, root and fruit by using Inductively Coupled Plasma - Optical Emission Spectrometer (ICP-OES).

\section{Results and Discussion}

\section{Standardization of $\mathrm{Zn}$ concentration for seed priming}

Tomato seeds responded variably towards the treatment at various concentrations of both bulk $\mathrm{ZnSO}_{4}$ and nano scale $\mathrm{ZnO}$ particles. Seed treated with 400ppm Nano $\mathrm{ZnO}$ recorded significant germination $(93.33 \%)$ and Seedling Vigour Index (919.80). 
Table.1 Effect of seed priming with different concentrations of nano $\mathrm{ZNO}$ and bulk $\mathrm{ZnSO}_{4}$ on germination, shoot length, root length and Seedling Vigour Index (SVI) in tomato

\begin{tabular}{|c|c|c|c|c|}
\hline $\begin{array}{c}\text { Concentration } \\
\text { (ppm) }\end{array}$ & $\begin{array}{c}\text { Germination } \\
(\%)\end{array}$ & $\begin{array}{l}\text { Root length } \\
(\mathrm{cm})\end{array}$ & $\begin{array}{l}\text { Shoot length } \\
\qquad(\mathrm{cm})\end{array}$ & SVI \\
\hline \multicolumn{5}{|l|}{ Zn source } \\
\hline Control & 63.33 & 2.16 & 1.30 & 249.97 \\
\hline Nano ZnO & 88.56 & 4.57 & 2.73 & 469.21 \\
\hline $\mathrm{ZnSO}_{4}$ & 82.66 & 4.77 & 2.66 & 497.66 \\
\hline SEM \pm & 1.60 & 0.04 & 0.06 & 4.89 \\
\hline $\mathrm{CD}(0.05)$ & 3.93 & 0.13 & 0.19 & 14.56 \\
\hline \multicolumn{5}{|c|}{ Interaction ( $\mathrm{Zn}$ source * concentration) } \\
\hline $\begin{array}{l}\text { Nano } \\
100\end{array}$ & 66.67 & 4.12 & 1.89 & 344.67 \\
\hline $\begin{array}{l}\text { Nano } \mathrm{ZnO} \\
200\end{array}$ & 66.67 & 4.7 & 3.43 & 524.40 \\
\hline $\begin{array}{l}\text { Nano } \quad \mathrm{ZnO} \\
400\end{array}$ & 93.33 & 6.97 & 3.22 & 919.80 \\
\hline $\begin{array}{l}\text { Nano } \\
600\end{array}$ & 73.33 & 6.52 & 3.65 & 856.97 \\
\hline $\begin{array}{l}\text { Nano } \quad \text { ZnO } \\
800\end{array}$ & 70.00 & 6.20 & 3.33 & 750.57 \\
\hline $\begin{array}{l}\text { Nano } \quad \text { ZnO } \\
1000\end{array}$ & 53.33 & 3.63 & 3.27 & 375.50 \\
\hline $\begin{array}{l}\text { Nano } \quad \text { ZnO } \\
1500\end{array}$ & 46.67 & 3.92 & 2.40 & 324.94 \\
\hline $\begin{array}{ll}\text { Nano } & \text { ZnO } \\
2000 & \\
\end{array}$ & 40.00 & 2.99 & 2.07 & 176.07 \\
\hline $\mathrm{ZnSO}_{4} 100$ & 66.00 & 4.13 & 1.69 & 395.8 \\
\hline $\mathrm{ZnSO}_{4} 200$ & 70.67 & 4.79 & 2.67 & 509.87 \\
\hline $\mathrm{ZnSO}_{4} 400$ & 73.33 & 5.44 & 4.13 & 612.67 \\
\hline $\mathrm{ZnSO}_{4} 600$ & 78.00 & 5.51 & 2.63 & 718.75 \\
\hline $\mathrm{ZnSO}_{4} 800$ & 80.00 & 6.17 & 4.39 & 834.71 \\
\hline $\mathrm{ZnSO}_{4} 1000$ & 56.67 & 4.63 & 2.63 & 425.11 \\
\hline $\mathrm{ZnSO}_{4} 1500$ & 50.00 & 4.317 & 2.17 & 346.31 \\
\hline $\mathrm{ZnSO}_{4} 2000$ & 46.67 & 2.69 & 2.10 & 199.07 \\
\hline $\mathrm{CD}(\mathrm{P}=0.05)$ & 6.37 & 0.22 & 0.31 & 24.64 \\
\hline SEM \pm & 2.33 & 0.094 & 0.13 & 10.37 \\
\hline CV (\%) & 4.70 & 4.90 & 1.40 & 5.25 \\
\hline
\end{tabular}


Table.2 Performance of tomato, influenced by different sources of $\mathrm{Zn}$ and method of application at 45 days after sowing

\begin{tabular}{|c|c|c|c|c|c|c|c|c|}
\hline Treatments & $\begin{array}{l}\text { no. of } \\
\text { branches }\end{array}$ & $\begin{array}{l}\text { Specific } \\
\text { Leaf } \\
\text { area } \\
\left(\mathrm{cm}^{2} / \mathrm{gm}\right)\end{array}$ & $\begin{array}{l}\text { Shoot } \\
\text { length } \\
(\mathrm{cm})\end{array}$ & $\begin{array}{l}\text { Root } \\
\text { length } \\
\text { (cm) }\end{array}$ & SCMR & $\begin{array}{l}\text { RWC } \\
(\%)\end{array}$ & $\begin{array}{l}\text { Shoot } \\
\text { Dry } \\
\text { weight } \\
\text { (gm) }\end{array}$ & $\begin{array}{l}\text { Root } \\
\text { dry } \\
\text { weight } \\
\text { (gm) }\end{array}$ \\
\hline \multicolumn{9}{|l|}{ Zn Sources } \\
\hline Nano ZnO & 5.00 & 138.42 & 49.45 & 37.21 & 52.92 & 86.50 & 46.00 & 8.40 \\
\hline $\mathrm{ZnSO}_{4}$ & 5.08 & 121.76 & 41.34 & 33.18 & 47.07 & 76.97 & 38.09 & 6.95 \\
\hline Control & 5.00 & 111.43 & 38.77 & 24.87 & 45.98 & 63.90 & 29.76 & 4.33 \\
\hline SEm \pm & 0.32 & 0.94 & 0.77 & 0.56 & 0.94 & 0.73 & 0.67 & 0.07 \\
\hline $\mathrm{CD}(\mathrm{P}=\mathbf{0 . 0 5})$ & 0.80 & 2.36 & 1.93 & 1.41 & 2.36 & 1.83 & 1.68 & 0.18 \\
\hline \multicolumn{9}{|c|}{ Method of application $\times \mathrm{Zn}$ sources } \\
\hline $\begin{array}{l}\text { Nano } \mathrm{ZnO} \\
\text { control(T1) }\end{array}$ & 4.33 & 109.01 & 35.50 & 26.10 & 43.47 & 66.96 & 30.66 & 6.10 \\
\hline $\begin{array}{l}\text { Nano } \mathrm{ZnO} \\
\text { Seed } \\
\text { priming } \\
\text { (T2) } \\
\end{array}$ & 5.33 & 152.39 & 59.5 & 46.07 & 57.07 & 71.16 & 43.30 & 8.03 \\
\hline $\begin{array}{l}\text { Nano ZnO } \\
\text { Seed } \\
\text { priming } \\
\text { +foliar } \\
\text { spray (T3) } \\
\end{array}$ & 5.00 & 169.43 & 57.13 & 36.80 & 68.30 & 80.07 & 54.48 & 8.57 \\
\hline $\begin{array}{l}\text { Nano } \mathrm{ZnO} \\
\text { Foliar } \\
\text { Spray (T4) } \\
\end{array}$ & 5.33 & 142.85 & 45.67 & 29.00 & 52.83 & 71.89 & 35.56 & 6.90 \\
\hline $\begin{array}{l}\mathrm{ZnSO}_{4} \\
\text { Control } \\
\text { (T1) }\end{array}$ & 4.33 & 109.01 & 35.50 & 28.10 & 43.47 & 66.96 & 30.66 & 6.10 \\
\hline $\begin{array}{l}\mathrm{ZnSO}_{4} \text { seed } \\
\text { priming } \\
\text { (T2) }\end{array}$ & 5.33 & 136.34 & 51.83 & 31.87 & 49.33 & 73.83 & 39.23 & 7.47 \\
\hline $\begin{array}{l}\mathrm{ZnSO}_{4} \text { seed } \\
\text { priming + } \\
\text { Foliar } \\
\text { spray (T3) }\end{array}$ & 5.00 & 144.00 & 61.87 & 33.87 & 54.33 & 72.87 & 49.52 & 8.00 \\
\hline $\begin{array}{l}\mathrm{ZnSO}_{4} \\
\text { Foliar } \\
\text { spray (T4) } \\
\end{array}$ & 5.67 & 127.70 & 36.13 & 27.00 & 46.90 & 66.163 & 32.91 & 6.23 \\
\hline $\operatorname{SEm} \pm$ & 0.65 & 1.87 & 1.55 & 1.13 & 1.88 & 1.47 & 1.34 & 0.134 \\
\hline $\begin{array}{l}\text { CD } \\
(P=0.05)\end{array}$ & 2.16 & 6.21 & 5.15 & 3.75 & 6.24 & 4.88 & 4.45 & 0.43 \\
\hline CV (\%) & 22.28 & 2.40 & 5.59 & 6.16 & 6.40 & 3.57 & 5.85 & 3.33 \\
\hline
\end{tabular}


Table.3 Interaction effect of different $\mathrm{Zn}$ sources and method of application on yield and $\mathrm{Zn}$ content in tomato

\begin{tabular}{|c|c|c|c|c|}
\hline Treatment & $\begin{array}{l}\text { Yield } \\
\text { (kg/plant) }\end{array}$ & $\begin{array}{l}\text { Fruit Zn } \\
\text { (mg/100gm) }\end{array}$ & $\begin{array}{l}\text { Leaf Zn } \\
\text { (mg/100gm) }\end{array}$ & $\begin{array}{l}\text { Root Zn } \\
(\mathrm{mg} / 100 \mathrm{gm})\end{array}$ \\
\hline Nano $\mathrm{ZnO}$ control(T1) & 3.54 & 2.60 & 2.80 & 2.20 \\
\hline Nano ZnO Seed priming (T2) & 4.30 & 4.91 & 4.24 & 3.03 \\
\hline $\begin{array}{l}\text { Nano } \quad \mathrm{ZnO} \quad \text { Seed } \\
\text { +foliar spray }(\mathrm{T} 3)\end{array}$ & 4.67 & 6.93 & 6.87 & 3.67 \\
\hline Nano ZnO Foliar Spray (T4) & 3.97 & 4.69 & 5.63 & 3.76 \\
\hline $\mathrm{ZnSO}_{4}$ Control (T1) & 3.54 & 2.60 & 2.80 & 2.20 \\
\hline $\mathrm{ZnSO}_{4}$ seed priming (T2) & 3.54 & 2.60 & 2.80 & 2.20 \\
\hline $\begin{array}{l}\mathrm{ZnSO}_{4} \text { Seed priming + Foliar } \\
\text { spray (T3) }\end{array}$ & 4.23 & 2.96 & 3.00 & 2.98 \\
\hline $\mathrm{ZnSO}_{4}$ Foliar spray (T4) & 4.43 & 5.19 & 5.19 & 3.47 \\
\hline Nano $\mathrm{ZnO}$ control (T1) & 3.83 & 3.60 & 4.27 & 3.10 \\
\hline SEm \pm & 0.08 & 0.13 & 0.11 & 0.21 \\
\hline $\mathrm{CD}(\mathrm{P}=0.05)$ & 0.27 & 0.41 & 0.37 & 0.70 \\
\hline CV $(\%)$ & 3.62 & 5.58 & 4.46 & 12.03 \\
\hline
\end{tabular}

The results from the bulk $\mathrm{ZnSO}_{4}$ treated seeds were not promising (Table 1). Among the different nano scale $\mathrm{ZnO}$ concentrations, 400ppm showed the maximum and increased concentration showed decreased seedling vigour index

\section{Field experiment}

The observations recorded at 45 DAS reveals the promotory effect of nano scale $\mathrm{ZnO}$. The result shows that there is a significant difference between both the $\mathrm{Zn}$ sources and also the method of application. The high root length was observed in nano $\mathrm{ZnO} \quad \mathrm{T}_{2}$ $(46.07 \mathrm{~cm})$ treatment followed by nano $\mathrm{ZnO}$ $\mathrm{T}_{3}(36.80 \mathrm{~cm})$. In $\mathrm{ZnSO}_{4}$ all the treatments had comparatively less root length than nano $\mathrm{ZnO}$. But all the $\mathrm{Zn}$ treated plants showed significantly highest root length compared to control $(26.10 \mathrm{~cm}) . \mathrm{ZnO} \mathrm{NPs}$ at all the methods of application proved to be effective in improving both root length and root dry weight it is represented in Table 2. These results confirmed that the physiological effects were related to the nano meter sized particles.

\section{Yield and Zn content}

The results revealed that the response of tomato to nanoscale $\mathrm{ZnO}$ was highly significant. In comparison with granular zinc sulphates and method of application, $\mathrm{ZnO}$ NPs with Seed Priming + Foliar spray recorded highest yield with highest $\mathrm{Zn}$ accumulation in fruit $(6.93 \mathrm{mg} / 100 \mathrm{gm})$, leaf $(6.87 \mathrm{mg} / 100 \mathrm{gm})$ and root $(3.67 \mathrm{mg} / 100 \mathrm{gm})$. Table 3 indicates the significant increase in yield and $\mathrm{Zinc}$ content by nano $\mathrm{ZnO}$ over granular $\mathrm{ZnSO}_{4}$ and control. $\mathrm{Zn}$ Sources and method of application on yield and $\mathrm{Zn}$ content in tomato. Due to promotory effects of nano $\mathrm{ZnO}$ on plant growth, yield and zinc content significantly increased over $\mathrm{ZnSO} 4$ and control. Such effects can be due to higher seedling vigour and early vegetative growth.

Nano particles (NPs) with small size and large surface area are expected to be the ideal 
material for use as a $\mathrm{Zn}$ fertilizer in plants. Currently use of nano materials has been expanded in every fields of science including agriculture. It has been stated that application of micronutrient fertilizers in the form of NPs is an important route to release required nutrients gradually and in a controlled way, which is essential to mitigate the problems of fertilizer pollutions (Naderi and Abedi, 2012). It is because of that when materials are transformed to a nano, they change their physical, chemical and biological characteristics as well as catalytic properties and even more increase the chemical and biological activities (Mazaherinia et al., 2010). The micronutrients in the form of NPs can be used in crop production to increase yield (Reynolds, 2002).

Recently it has been studied that nano $\mathrm{ZnO}$ positive impact on germination, growth and yield of peanut (Prasad et al., 2012). It has been reported from pot culture experiments on wheat plants that increasing seed zinc content from $0.25 \mu \mathrm{g}$ per seed to $0.70 \mu \mathrm{g}$ per seed significantly improved root and shoot growth under Zn deficiency. Hence it may be concluded that high $\mathrm{Zn}$ content in seed could act as a starter fertilizer. Ajouri et al., (2004) reported that seed priming with $\mathrm{Zn}$ was very effective in improving seed germination and seedling development in barley. These results may indicate that high $\mathrm{Zn}$ concentration in seeds has very important physiological roles during seed germination and early seedling growth. In our study we have standardized the $\mathrm{Zn}$ concentration for Tomato seeds using nano $\mathrm{ZnO}$. At $400 \mathrm{ppm}$ nano $\mathrm{ZnO}$ tomato seeds showed significantly highest germination percentage, root length, shoot length and seedling vigour index (Table 1). A significant increment in the germination, shoot length, root length and seedling vigour index was observed in the nano $\mathrm{ZnO}$ standardized concentration compare to the common $\mathrm{ZnSO}_{4}$ at the same concentrations.
In one of the study on groundnut seeds with nano $\mathrm{ZnO}$ particles with a concentration of $1000 \mathrm{ppm}$ also reported the significant increase in germination; shoot length, root length and vigour index (Prasad et al., 2012). In one of the study on mung (Vigna Radiata) similar results were found with nano $\mathrm{ZnO}$ seed priming and also been observed that beyond optimum concentration growth was inhibited (Pramod et al., 2011). Another report showed that effect of $\mathrm{ZnO}$ nanoparticle on the seed germination and root growth in black gram (Cicer arietinum) seeds on the reactivity of phytohormones especially indole acetic acid (IAA) involved in the phyto stimulatory actions. Due to oxygen vacancies, the oxygen deficient, i.e. zinc-rich $\mathrm{ZnO}$ nano particle increased the level of IAA in roots (sprouts) which in turn indicate the increase in the growth rate of plants (Avinash and Pandey et al., 2010). Reports on mung (Vigna radiate) and in gram (Cicer arietinum) by using nano $\mathrm{ZnO}$ particle in agar method, which found to affect the growth of mung and gram seedlings at different concentrations. The maximum effect was found at $20 \mathrm{ppm}$ for mung and $1 \mathrm{ppm}$ for gram (Pramod Mahajan et al., 2011).

Method of application of fertilizer is the most important concerned to the uptake and translocation onto the different parts of plant. Foliar fertilization is an important tool for the sustainable and productive management of crops. The ability of plant leaves to absorb water and nutrients was recognized approximately three centuries ago (Fernández and Eichert, 2009). The application of nutrient solutions to the foliage of plants as an alternative means of fertilize to crops such as grass. Spraying with 0.5 per cent $\mathrm{ZnSO}_{4}$ gave significantly higher peanut pod yield compared to no spraying. However, soil application of $10 \mathrm{~kg} / \mathrm{ha} \mathrm{ZnSO}_{4}$ during sowing gave yield on par with control plants without $\mathrm{ZnSO}_{4}$ application. This indicates that 
groundnut responds to foliar spray but not to soil application (Channabasavanna and Setty, 1993). The effectiveness of various synthetic and natural chelates has been widely investigated (Alvarez and Gonzalez, 2006; Gonzalez et al., 2007; Prasad and Sinha, 1981). Apart from their effectiveness, application of chelates is generally expensive and may result in potential leaching risk because the more mobile the chelate, or the less biodegradable the carrier, the greater the risk of leaching (Gonzalez et al., 2007). Zinc sulphate, which is highly soluble, can easily be taken up by plants but is known to fall off quickly. The retention time in the plant system is low. So the bioavailability of nutrients for long period was not sure with the use of $\mathrm{ZnSO}_{4}$. If the plants are soft or sensitive and if the conditions are harsh like high temperatures, $\mathrm{ZnSO}_{4}$ has a large salt index, which may burn the plant. Moreover, the zinc content in the mixture is usually very low (9-12 \%). (Brown et al., 1993; Fageria et al., 2002)

In this study different treatments with nano $\mathrm{Zn}$ oxide particle and $\mathrm{ZnSO}_{4}$ such as seed priming, foliar application and seed priming with foliar application were imposed to examine the treatment effect. Results suggest that nano $\mathrm{ZnO}$ form is absorbed by plants to a larger extent unlike bulk $\mathrm{ZnSO}_{4}$. Nano $\mathrm{ZnO}$ has proved to be more effective in enhancing productivity and absorption of $\mathrm{Zn}$ because of high surface area to volume ratio. Better growth and 12-14 days early flowering was observed in nano $\mathrm{ZnO}$ treated onion plants at 20 and $30 \mu \mathrm{g} / \mathrm{ml}$ compared to control onion plants (Laware, 2014).

\section{References}

Abdu-Baki, A. A. and Anderson, J. D. (1973), Vigour determination in soybean by multiple criteria. Crop Science, 13: 630-633.
Ajouri, A., Asgedom, H. and Becker, M., 2004, Seed priming enhances germination and seedling growth of barley under conditions of $\mathrm{P}$ and $\mathrm{Zn}$ deficiency. Journal of Plant Nutrition and Soil Science, 167: 630-636.

Alvarez, J. M. and G, D., 2006, Zinc transformations in neutral soil and zinc efficiency in maize fertilization. Journal of Agricultural and Food Chemistry, 54: 9488-9495.

Avinash, C. Pandey., Sharda, S. Sanjay., and Raghvendra, S. Yadav., 2010, Application of $\mathrm{ZnO}$ nano particles in influencing the growth rate of Cicer arietinum. Journal of Experimental Nano science, 5 (6): 488-497.

Black, R. E., 1998, Therapeutic and preventive effects of zinc on serious childhood infectious diseases in developing countries. American Journal of Clinical Nutrition, 68: 476-479.

Brown, P. H., Cakmak, I. and Zhang, Q., 1993, Form sand function of zinc in plants. In: Zinc In Soil And Plants, Dordrecht, The Netherlands: Kluwer Academic Publisher, Ed. A. D. Robson, 93- 106.

Channabasavanna, A. S. and Setty, R. A., 1993, Effect of nitrogen, ferrous sulphate and zinc sulphate on groundnut yield in deep black soils. Indian Journal of Agronomy, 38: 329-330.

Fageria, N. K., Baligar, V. C. and Clark, R. B., 2002, Micronutrients in crop production. Advances In Agronomy, 77:189 -272.

FAO/WHO, 2002, Human vitamin and mineral requirements - Report of a joint FAO/WHO expert consultation Bangkok, Thailand, FAO, Rome. Chapter 16. Zinc, 257-270.

Fernandez, V., and T. Eichert. 2009. Uptake Of Hydrophilic Solutes Through Plant Leaves: Current State Of Knowledge And Perspectives Of Foliar 
Fertilization. Critical Reviews In Plant Sciences, 28: 36-68.

Ghaly, A. E. and Alkoaik, F. N., 2010, Extraction of protein from common plant leaves for use as human food. American Journal of Applied Science, 7: $331-342$.

Ghaly, A. E. and Alkoaik, F. N., 2010, Extraction of protein from common plant leaves for use as human food. American Journal of Applied Science, 7: $331-342$.

Ghaly, A. E., 2009, The black cutworm as a potential human food. American Journal of Biochemistry and Biotechnology, 5: 210- 220 .

Gonzalez, D., Obrador, A. and Alvarez, J. M., 2007, Behaviour of zinc from six organic fertilizers applied to a navy bean crop grown in a calcareous soil. Journal of Agricultural and Food Chemistry, 55: 7084-7092.

Gui-Rui Yu, Takuji Miwa, Keiichi Nakayama, Nobuhiro Matsuoka and Hisashi Kon., 2000, A proposal for universal formulas for estimating leaf water status of herbaceous and woody plants based on spectral reflectance properties. J. Plant and Soil, 227: 47-58

Hacisalihoglu, G., Hart, J. J., Wang, YI. H., Cakmak, I. and Kochian, V. L., 2003, Zinc efficiently is correlated with enhanced expression and activity of zinc-requiring enzymes in wheat. Plant Physiology, 131: 595-602

Laware S.L. and Shilpa Raskar, 2014. Influence of zinc oxide nanoparticles on growth, flowering and seed Productivity in onion. International J. Curr. Microbiol. App. Sci, 3(7): 874-881.

Lin, D., and B. Xing. 2007. Phytotoxicity of nanoparticles: Inhibition of seed germination and root growth. Environmental Pollution 150: 243-250.

Mazaherinia, S., Astaraei, A.R., Fotovat, A., Monshi, A. 2010, Nano iron oxide particles efficiency on Fe, Mn, Zn And $\mathrm{Cu}$ concentrations in wheat plant. Word Applied Science Journal, 7(1): 36-40

Meenakshi, J. V., Johnson, N. L., Manyong, V. M., Degroote, H. And Javelosa, J., 2010, How cost-effective is biofortification in combating micronutrient malnutrition? An Ex ante Assessment. World Dev, 38: 64-75.

Naderi, M.R., and Abedi, A., 2012, Application of nanotechnology in agriculture and refinement of environmental pollutants. Journal of Nanotechnology, 11(1): 18-26

Pijls, L., Ashwell, M. and Lambert, J., 2009, EURRECA-A network of excellence to align European micronutrient recommendations. Food Chemistry, 113:748-753.

Pramod, M., Dhoke, S. K. and Khanna, A. S., 2011, Effect of Nano-ZnO Particle Suspension on Growth of Mung (Vigna radiata) and Gram (Cicer arietinum) Seedlings Using Plant Agar Method. Journal of Nanotechnology, 2: 121-133.

Prasad, B. and Sinha, M. K., 1981, The relative efficiency of zinc carriers on growth and zinc nutrition of corn. Plant and Soil, 62: 45-52.

Prasad, T.N.V.K.V., Sudhakar, P., Sreenivasulu, Y., Latha, P., Munaswamy, Y., Raja Reddy, K., Sreeprasad, T. S., Sajanlal, P. R. and Pradeep, T., 2012, Effect of nanoscale zinc oxide particles on the germination, growth and yield of peanut. Journal of Plant Nutrition, 35(6): 905-927.

Quasem, J. M., Mazahreh, A. S. and AbuAlruz, K., 2009, Development of vegetable based milk from decorticated sesame (Sesamum indicum). American Journal of Applied Science, 6: 888-896.

Reynolds, G.H., 2002. Forward to the future nanotechnology and regulatory policy. Pacific Research Institute, 24:1-23. 
Shah, V., and I. Belozerova. 2009. Influence of metal nanoparticles on the soil microbial community and germination of lettuce seeds. Water, Air and Soil Pollution 97: 143-148.

Shankar, A. H. and Prasad, A. S., 1998, Zinc and immune function: the biological basis of altered resistance to infection. American Journal of Clinical Nutrition, 68: 447-463.

Stein, A. J., Meenakshi, J. V., Qaim, M., Nestel, P. and Sachdev, H. P. S., 2008, Potential impacts of iron biofortification in India. Soc. Sci. Med., 66: 1797-1808.
Wheeler, S., 2005, Factors influencing agricultural professional's attitudes toward organic agriculture and biotechnology Centre For Regulation And Market Analysis, University Of South Australia.

Zhang, L., F. Hong, S. Lu, and C. Liu. 2005. Effect of nano $\mathrm{TiO} 2$ on strength of naturally aged seeds and growth of spinach. Biological Trace Element Research 105: 83-91.

Zhao, F. J. and Mcgrath, S. P., 2009, Biofortification and phytoremediation. Current Opinion of Plant Biology, 12: 373- 380.

\section{How to cite this article:}

Hajira Khanm, B.A. Vaishnavi and Shankar, A.G. 2018. Raise of Nano-Fertilizer Era: Effect of Nano Scale Zinc Oxide Particles on the Germination, Growth and Yield of Tomato (Solanum lycopersicum). Int.J.Curr.Microbiol.App.Sci. 7(05): 1861-1871.

doi: https://doi.org/10.20546/ijcmas.2018.705.219 